\title{
PELAKSANAAN PROGRAM PEMBIASAAN KONSUMSI MAKANAN SEHAT DI DANDELION DAYCARE PLUS DEPOK
}

\author{
Via Amalia ${ }^{1}$; Nurfadilah $^{1}$ \\ ${ }^{1}$ Program Studi Pendidikan Guru Pendidikan Anak Usia Dini, Fakultas Psikologi dan Pendidikan, \\ Universitas Al Azhar Indonesia, Jalan Sisingamangaraja Kebayoran baru, Jakarta Selatan 12110 \\ E-mail: nurfadilah@uai.ac.id
}

\begin{abstract}
Abstrak- Kesehatan penting bagi perkembang dan pertumbuhan anak yang dipengaruhi oleh makanan yang anak konsumsi. Pertumbuhan dan perkembangan anak saat usia dini mempengaruhi tumbuh kembang anak sampai dewasa. Namun, kurangnya minat anak dalam konsumsi makanan sehat karena anak mulai pilih - pilih makan yang anak inginkan. Penelitian ini bertujuan untuk mengetahui dan mendeskripsikan pelaksanaan dalam membiasakan anak konsumsi makan makanan sehat di TPA Dandelion Daycare Plus Depok. Metode yang digunakan pada penelitian ini adalah pendekatan kualitatif deskriptif dengan teknik pengumpulan data wawancara, observasi dan dokumentasi. Teknik analisis data menggunakan model Miles and Hubermen melalui pengumpulan data, reduksi data, penyajian data, dan penarikan kesimpulan. Hasil penelitian menunjukkan bahwa pelaksanaan pembiasaan mengkonsumsi makanan sehat, Dandelion daycare menggunakan kegiatan pembiasaan harian, metode mini garden, fun cooking, dan fieldtrip dengan media yang digunakan APE, papan tulis menu, peralatan fun cooking, media garden beserta peralatan berkebun,serta melakukan evaluasi setiap hari yang dilakukan antara educare dan orangtua melalui buku komunikasi.
\end{abstract}

Kata kunci: Program Pembiasaan, Makanan Sehat, Daycare

Abstract - Health is important for the development and growth of children who are influenced by the food that children consume. Growth and development of children at an early age affects the development of children into adulthood. However, the lack of children's interest in consuming healthy foods is because children are starting to choose what they want to eat. This study aims to identify and describe the implementation of getting children to eat healthy food at Dandelion Daycare Plus Depok. The method used in this study is a descriptive qualitative approach with data collection techniques, interviews, observation and documentation. Data analysis techniques used the Miles and Hubermen model through data collection, data reduction, data presentation, and drawing conclusions. Based on the results of interviews, observation and documentation, it can be concluded that in the implementation of familiarizing children with eating healthy Dandelion daycare through daily habituation activities, the mini garden method, fun cooking, and field trips with the media used by APE, menu boards, fun cooking equipment, media gardens along with gardening tools, as well as conducting daily evaluations between educare and parents through communication books, and once a month between the head of daycare, educare, and the daycare chef.

Keyword: Habitual Program, Healthy Food, Daycare 


\section{PENDAHULUAN}

$\mathrm{A}$ nak usia dini merupakan anak yang sedang berada pada fase usia keemasan (golden age), pada usia ini anak perlu diberikan stimulasi berupa pendidikan anak usia dini (PAUD). Anak perlu untuk dikembangkan dengan mengoptimalkan berbagai jenis perkembangan, baik dari perkembangan fisik sampai dengan perkembang-an emosional.

Dalam mengoptimalkan perkembangannya, penting bagi anak untuk belajar menjaga kesehatan tubuhnya. Karena itu, tahun - tahun masa pendidikan anak usia dini adalah waktu terbaik bagi seorang anak untuk memulai pola hidup dan makan yang sehat, dengan fokus pada aktivitas rutin dan makanan sehat serta bergizi seimbang.

Menurut Mulyasa (2012) PAUD tidak hanya dalam lingkungan pendidikan formal, tetapi juga dalam lingkungan nonformal. Salah satu layanan PAUD Nonformal ialah tempat penitipan anak (TPA) atau biasa disebut daycare menyelenggarakan program pendidikan dan pengasuhan pada anak dari usia lahir sampai enam tahun. Salah satu layanan yang diberikan oleh TPA ialah pemberian makan, makanan yang disiapkan untuk dikonsumsi anak harus makanan sehat yang mengandung gizi seimbang, terdapat protein, karbohidrat, vitamin, air dan mineral.Makanan sehat yang dikonsumsi anak sangat penting untuk perkembangan dan pertumbuhan anak. Dengan mengkonsumsi makanan sehat maka kebutuhan nutrisi dapat terpenuhi, terutama untuk anak usia dini, makanan merupakan sumber tenaga untuk anak dalam melakukan aktivitas seharihari, meningkatkan kecerdasan otak, dan kesehatan anak.

Terdapat berbagai macam permasalahan yang terjadi pada anak terkait mengkonsumsi makanan sehat. Menurut Gordon dan Anne dalam buku Contemporary Nutrition (2013) kekhawatiran yang terjadi saat ini ialah perubahan perilaku makan anak. Rata-rata pertambahan berat badan tahunan hanya $2-3$ kilogram, dan rata - rata pertambahan tinggi tahunan hanya 7,5 - $10 \mathrm{~cm}$ antara usia anak $2-$ 6 tahun. Tingkat pertumbuhan yang menurun menyebabkan nafsu makanpun menurun, atau biasa disebut "pilih - pilih makan" dibandingkan dengan bayi. Karena nafsu makan anak yang berkurang, perencanaan yang memenuhi kebutuhan nutrisi anak menimbulkan tantangan khusus bagi pengasuh.

Penyebab dari penurunan nafsu makan adalah faktor fisik yaitu anak menderita suatu penyakit dan faktor psikis yaitu anak yang bosan dengan makanan yang dimakan. Faktor ini berkaitan dengan perkembangan dimana usia prasekolah mengalami masa peralihan bentuk makanan dari lunak ke makanan biasa (Saputri, 2015). Anak - anak cenderung waspada terhadap makanan yang baru ia konsumsi, anak memiliki rasa tidak ingin mengkonsumsi makanan yang tidak dikenal. Karena itu, membiasakan anak konsumsi makanan sehat sejak dini perlu dilakukan dengan berbagai macam upaya, seperti bagaimana menyajikan makanan sehat dengan menarik, melibatkan anak dalam proses menyiapkan makanan serta memberikan penjelasan terkait makanan yang akan anak konsumsi. Dalam membiasakan anak konsumsi makanan sehat dibutuhkan pengetahuan serta kesabaran guru dan pengasuh dalam mempertahankan nafsu makan anak, juga untuk membangun kebiasaan makan anak yang baik.

Belum semua TPA atau daycare yang memiliki program untuk mendukung kebiasaan anak yang baik dalam konsumsi makan makanan sehat. Namun peneliti menemukan satu daycare yang memiliki program makan sehat dan berhasil membangun kebiasaan makan anak yang baik, yaitu Dandelion daycare plus. Berdasarkan hasil pengamatan melalui sosial media Dandelion daycare Depok, bahwa ternyata terdapat keberhasilan dalam melakukan program pembiasaan konsumsi makanan sehat yang merupakan sebagai salah satu layanan di daycaremelalui kegiatan pembiasaan harian, metode mini garden, fun cooking dan field trip, hal tersebut terbukti dengan terpenuhinya kebutuhan setiap anak dalam segi konsumsi makan sehat, dan semua anak yang berusia 4 6 tahun yang berjumlah 6 anak mau konsumsi makan makanan sehat yang telah disediakan oleh daycare. Guru dan pengasuh memberikan pengetahuan dan memotivasi anak bahwa mengkonsumsi makanan sehat terutama sayur baik untuk kesehatan tubuhnya. Tidak hanya memotivasi, kepala sekolah, guru dan pengasuh juga merupakan fasilitator dan pendukung dalam menyediakan makanan sehat yang bergizi seimbang terutama sayuran. Maka dari itu, Dandelion Daycare Plus memberikan 
pembelajaran serta pemenuhan gizi melalui program makan sehat. Karena pentingnya memenuhi kebutuhan anak dalam mengkonsumsi makanan sehat sejak dini, maka dilakukan penelitian lebih mendalam terkait pelaksanaan Program Pembiasaan Konsumsi Makanan Sehat Anak Usia 4 - 6 Tahun di Tempat Penitipan Anak (TPA) Dandelion Daycare Plus, Depok.

Bredekamp (dalam Sujiono, 2013) berpendapat bahwa dalam pelaksanaannya untuk mencapai tujuan program, ada beberapa strategi bagi anak usia dini yang berorientasi pada:

1. Tujuan yang mengarah pada tugas - tugas perkembangan disetiap rentangan usia anak

2. Materi yang diberikan harus mengacu dan sesuai dengan karakteristik dan kebutuhan yang sesuai dengan taraf perkembangan anak $(D A P=$ Developmentally Approriate Practice)

3. Metode yang dipilih seharusnya bervariasi sesuai dengan tujuan kegiatan belajar dan mampu melibatkan anak secara aktif dan kreatif serta menyenangkan

4. Media dan lingkungan bermain yang digunakan haruslah aman, nyaman, dan menimbulkan ketertarikan bagi anak dan perlu adanya waktu yang cukup untuk bereksplorasi

5. Evaluasi yang baik dan dianjurkan untuk dilakukan adalah rangkaian sebuah assessment melalui observasi partisipatif terhadap segala sesuatu yang dilihat, didengar dan diperbuat oleh anak.

Berbagai program pembiasaan dapat dirancang dan dilakukan lembaga untuk membiasakan anak mengkonsumsi makan makanan sehat, beberapa cara yang dapat dilakukan yaitu melalui berbagai metode seperti mini garden, fun cooking, dan field trip.

\section{Metode Berkebun}

Menurut Rachmawati (2018) di sekolah taman mini atau mini garden adalah ruang kecil tanah dari area luar sekolah yang digunakan untuk menanam tanaman yang produktif bagi siswa dan guru, dan merupakan sumber belajar alternatif. Adapun menurut Wardani (2019) berkebun adalah kegiatan memanfaatkan sebidang tanah atau lahan sebagai tempat menanam tumbuhan.

\section{Metode Fun cooking}

Menurut Amaros dan Rohita (2018) kegiatan fun cooking merupakan kegiatan dimana anak dapat mencoba langsung membuat makanan dari bahan yang mentah hingga menjadi matang melalui proses - proses dan bimbingan guru. Adapun menurut Dewi (2019) fun cooking merupakan sebuah kegiatan menyenangkan yang secara langsung melibatkan anak untuk bergerak dan berkreasi dengan menggunakan jari - jari tangan mereka. Fun cooking merupakan kegiatan yang tepat untuk anak usia dini karena mampu menumbuhkan dan meningkatkan pengalaman belajar anak secara langsung.

\section{Metode Field Trip}

Adapun menurut Yati (2016) metode field trip merupakan metode penyampaian materi pelajaran dengan cara membawa langsung siswa ke obyek di luar kelas atau lingkungan yang berdekatan dengan sekolah agar siswa dapat mengamati atau mengalami secara langsung. Adapun menurut Juniarti (2015) kunjungan lapangan atau field trip adalah suatu perjalanan sekolah atau studi lapangan yang dilakukan oleh guru dan peserta didiknya untuk melihat langsung objek yang akan dikunjungi agar anak - anak merasakan pengalaman nyata.

Dari beberapa pendapat di atas dapat disampaikan bahwa dalam melaksanaan program pembiasaan diperlukan metode yang bervariasi dan dapat melibatkan anak secara langsung, menggunakan media yang aman dan menyenangkan untuk anak, serta melakukan evaluasi untuk mengumpulkan segala informasi yang dibutuhkan demi menilai ketercapaian suatu tujuan.

Terdapat beberapa syarat yang perlu diperhatikan dalam melakukan pembiasaan, yaitu (Arief, 2002):

1. Mulai pembiasaan itu sebelum terlambat, jadi sebelum anak itu mempunyai kebiasaan lain yang berlawanan dengan hal - hal yang dibiasakan. 
2. Pembiasaan itu hendaknya terus menerus (diulang - ulang) dijalankan secara teratur sehingga akhirnya menjadi suatu kebiasaan yang otomatis.

3. Pembiasaan hendaklah konsekuen, bersikap tegas dan tetap teguh terhadap pendirianyang telah diambilnya. Jangan memberi kesempatan kepada anak untuk melanggar pembiasaan yang telah ditetapkan itu.

4. Pembiasaan yang mula - mulanya mekanistis itu harus menjadi pembiasaan yang disertai kata hati anak sendiri.

Dengan cara mengulang - ulang diharapkan anak akan terbiasa melakukannya. Menurut Djamarah (2010) meskipun pembiasaan telah fungsional dalam diri peserta didik, tetapi pengawasan tetap harus dilakukan selama mereka di sekolah, dan bahkan jika mungkin di luar sekolah. Dengan melakukan pengawasan, maka ketika anak didik melakukan kesalahan guru dapat melakukan perbaikan.

\section{METODE PENELITIAN}

Penelitian ini menggunakan metode penelitian kualitatif deskriptif. Lokasi penelitian ini adalah di Dandelion Daycare Plus Depok. Data penelitian bersumber dari kepala sekolah dan 3 guru. Penelitian ini menggunakan teknik triangulasi yaitu wawancara, observasi, dokumentasi. Analisis data yang digunakan pada penelitian ini model Miles and Hubermen melalui pengumpulan data, reduksi data, penyajian data, dan penarikan kesimpulan (Sugiono, 2012)

Teknik keabsahan data yang digunakan dalam penelitian ini adalah teknik triangulasi. Triangulasi diartikan sebagai teknik pengumpulan data yang bersifat menggabungkan dari berbagai teknik pengumpulan data dan sumber data yang telah ada. Peneliti menggunakan observasi partisipatif, wawancara mendalam dengan kepala daycare dan guru/educare, dan dokumentasi terkait program pembiasaan konsumsi makanan sehat untuk sumber data yang sama secara serempak.

\section{HASIL DAN PEMBAHASAN}

Pembiasaan konsumsi makanan sehat sejak dini sangatlah dibutuhkan oleh anak, sebab saat usia dini anak cenderung sulit makan makanan sehat terutama sayur dan buah, maka dari itu perlu dilakukan pelaksanaan dalam membiasakan anak sejak dini sebagai salah satu cara untuk anak mau belajar dan mulai mengkonsumsi makanan sehat sehingga menimbulkan kebiasaan yang baik pada anak sampai saat dewasa dalam mengkonsumsi makanan yang sehat. Dandelion Daycare Plus memiliki program untuk membiasakan anak dalam mengkonsumsi makanan sehat.

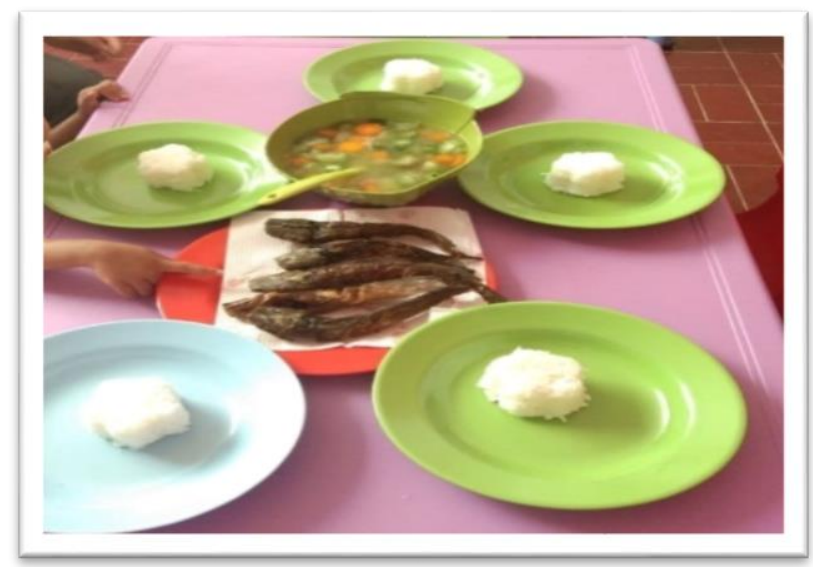

Gambar 1. variasi menu makan siang

Berdasarkan hasil penelitian, dalam pelaksanaan program pembiasaan konsumsi makan makanan sehat Dandelion Daycarde Plus memiliki tujuan membiasakan konsumsi makanan sehat pada anak, membiasakan anak hidup sehat, mendukung program pemerintah untuk generasi sehat Indonesia, menjalankan program daycare yang sudah ditetapkan sebagai bagian mutu daycare. Dalam pelaksanaan tidak ada juknis hanya rancangan menu daycare. Adapun metode yang dilakukan untuk membiasakan anak konsumsi makan sehat di Dandelion melalui metode pembiasaan harian pada kegiatan makan pagi, siang, malam, dan snack sore, selanjutnya metode berkebun/mini garden yang menjadi program unggulan dari Dandelion daycare untuk membiasakan anak mengkonsumsi makanan sehat terutama berupa sayur, dilakukan di kebun daycare di mana anak secara langsung terlibat menanam benih yang telah disediakan, merawat dengan menyiram setiap hari, memanen dan mengolah hasil panen. Sesuai dengan pendapat Rachmawati (2018) di sekolah taman mini atau mini garden adalah ruang kecil tanah dari area luar sekolah yang digunakan untuk menanam tanaman yang produktif bagi siswa dan guru, dan merupakan sumber belajar alternatif. 
Adapun metode selanjutnya yang dilakukan ialah metode fun cooking di mana hasil panen dari mini garden akan di olah dalam kegiatan fun cooking, tidak hanya itu anak juga memasak menu lain, seperti cemilan sehat, kue, dan lain lain. Sependapat dengan Amaros dan Rohita (2018) kegiatan fun cooking merupakan kegiatan dimana anak dapat mencoba langsung membuat makanan dari bahan yang mentah hingga menjadi matang melalui proses - proses dan bimbingan guru. Selanjutnya, metode field trip dengan berkunjung ke warung sayur dan mini market. Sesuai dengan pendapat Juniarti (2015) kunjungan lapangan atau field trip adalah suatu perjalanan sekolah atau studi lapangan yang dilakukan oleh guru dan peserta didiknya untuk melihat langsung objek yang akan dikunjungi agar anak - anak merasakan pengalaman nyata.

Adapun media yang digunakan untuk mendukung kegiatan berupa papan tulis menu, APE sentra bermain peran pedagang dan memasak, peralatan fun cooking, media garden serta peralatan berkebun. Hal ini sesuai dengan pendapat Bredekamp (dalam Sujiono, 2013) media dan lingkungan bermain yang digunakan haruslah aman, nyaman, dan menimbulkan ketertarikan bagi anak dan perlu adanya waktu yang cukup untuk bereksplorasi.

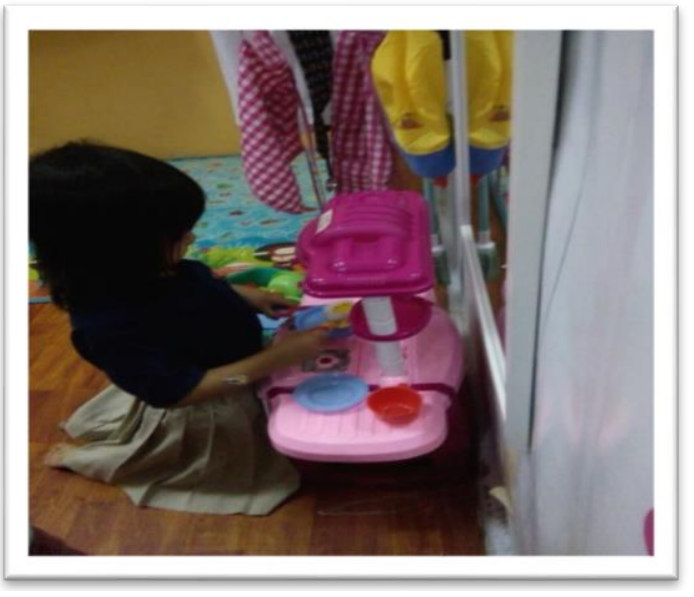

Gambar 2. bermain memasak dengan media APE kompor mainan

Di samping itu, evaluasi dalam program pembiasaan konsumsi makan sehat, keempat subjek mengatakan jika evaluasi dilakukan per hari antara educare, koki beserta orangtua juga ditulis melalui laporan di buku komunikasi daycare dan perbulan antara kepala daycare,educare serta koki membahas terkait menu makanan yang paling banyak disukai dan kurang disukai anak serta menu untuk anak yang alergi terhadap suatu makanan. Hal itu juga sependapat dengan Bredekamp (dalam Sujiono, 2013) evaluasi yang baik dan dianjurkan untuk dilakukan adalah rangkaian sebuah assessment melalui observasi partisipatif terhadap segala sesuatu yang dilihat, didengar dan diperbuat oleh anak.

Keempat subjek penelitian dalam melakukan pembiasaan konsumsi makanan sehat pada anak dilakukan rutin setiap hari dalam pelayanan kegiatan makan harian, mini garden dilakukan setiap hari anak mendapatkan jadwal merawat dan menyiram tanaman, fun cooking satu bulan sekali, dan field trip $1-2$ kali dalam satu tahun. Hal ini sependapat dengan Arief (2002) bahwasanya dalam pembiasaan itu hendaknya terus menerus (diulang - ulang) dijalankan secara teratur sehingga akhirnya menjadi suatu kebiasaan yang otomatis.

Keempat subjek penelitian mengatakan bahwasanya keterlibatan orangtua juga dilakukan dalam membiasakan anak untuk hidup sehat dengan diskusi kondisi anak dan evaluasi pola makan anak, menginformasikan menu di buku harian, memenuhi kebutuhan masing - masing anak, melibatkan orangtua dalam kegiatan mini garden serta parent day dimana orangtua bercerita dalam kelas, namun pengawasan di rumah masih kurang diberlakukan. Menurut Djamarah (2010) meskipun pembiasaan telah fungsional dalam diri peserta didik, tetapi pengawasan tetap harus dilakukan selama mereka di sekolah, dan bahkan jika mungkin di luar sekolah. Dengan melakukan pengawasan, maka ketika anak didik melakukan kesalahan guru dapat melakukan perbaikan.

\section{SIMPULAN DAN SARAN}

Berdasarkan hasil pembahasan terkait pelaksanaan program pembiasaan konsumsi makan makanan sehat dapat disimpulkan bahwa pelaksanaan program pembiasaan konsumsi makanan sehat di Dandelion Daycare dilaksanakan melalui metode pelayanan kegiatan harian, mini garden, fun cooking dan field trip dengan media yang digunakan berupa APE, papan tulis menu, peralatan fun cooking, dan media garden beserta kelengkapan 
berkebun, serta melakukan evaluasi setiap hari antara educare dan orangtua melalui buku komunikasi, dan setiap satu bulan sekali antara kepala daycare, educare, dan koki daycare.

Beberapa saran yang dapat dikemukakan dari hasil penelitian ini adalah sebagai berikut: pertama, sebaiknya educare dapat terus meningkatkan pengetahuan yang merupakan menjadi dasar untuk menambah keterampilan dalam menarik perhatian anak dengan menggunakan metode dan media yang menyenangkan. Kedua, sebaiknya lembaga meneruskan kebiasaan makan yang baik ini di rumah dengan berkomunikasi bersama orangtua untuk mengawasi anak saat konsumsi makanan sehat di rumah.

\section{DAFTAR PUSTAKA}

Amaros, Y., \& Rohita, R. (2018). Peran kegiatan fun cooking dalam kemampuan sosial emosional dan bahasa anak. Jurnal Al-Azhar Indonesia Seri Humaniora, 4(4), 256-264.

Arief, A. (2002). Pengantar ilmu dan metodologi pendidikan Islam. Jakarta: Ciputat Pers.

Dewi, A. (2019). Evaluasi program fun cooking di ar-raudah play group \& kindergarten Bandar Lampung. Skripsi: UIN Raden Intan Lampung.

Djamarah, S.B. (2010). Guru dan anak didik dalam interaksi edukatif. Jakarta: PT Rineka Cipta.
Juniarti, Y. (2015). Peningkatan Kecerdasan Naturalis Melalui Metode Kunjungan Lapangan (Field Trip). Jurnal Pendidikan Usia Dini Vol. 9 Edisi 2.

Mulyasa. (2012). Manajemen PAUD. Bandung: Remaja Rosdakarya.

Rachmawaty, M. (2018). Improving Beginning Reading Skill Through Mini Garden. Education and Humanities Research, Vol. 212.

Saputri, M.P., Supriyono, M. (2015). Efektivitas variasi makanan terhadap peningkatan nafsu makan anak usia prasekolah di kelurahan kuningan semarang utara. Karya Ilmiah: STIKES Telogorejo Semarang.

Sugiyono. (2012). Metode penelitian kuantitatif, kualitatif dan pengembangan $R \& D$. Bandung: Alfabeta.

Sujiono, Y.N. (2013). Konsep dasar pendidikan anak usia dini. Jakarta: PT Indeks.

Wardani, R. (2019). Pengenalan sains kehidupan melalui sentra berkebun untuk anak usia dini di TK Anak Cerdas Ungaran. Skripsi: UNNES.

Wardlaw, G.M., Smith, A.M. 2013. Contemporary nutrition (ninth edition).

Yati, P. (2016). pendidikan karakter anak usia dini melalui meotde pembelajaran field trip. Jurnal Lentera, Vol. XVIII, No. 1. 